\title{
Incidence of base rot and wilt, sanitary severity and influence about seed pathology by cultivars of common bean (Phaseolus vulgaris)
}

\author{
Incidência de podridão-do-colo e severidade fitossanitária e impacto na patologia \\ de sementes de cultivares comerciais de feijoeiro-comum (Phaseolus vulgaris)
}

\author{
Mateus Paulino Braga' (D), Luana Machado Rezende' (D), Lucinete Martins Barbosa Estrela' (D, \\ Natanael Marcos Lemes ${ }^{1}$ (D), Anderson Rodrigues Rietjens' ${ }^{1}$, Ana Livia Lemos Oliveira' (D), \\ Jakelinny Martins Silva' (D), Laryssa Lucas Araújo Silva' (D), Milton Luiz da Paz-Lima'* (D)
}

\begin{abstract}
The objective of this work was to conduct a temporal evaluation of incidence of rot base and sanitary severity, and to relate the impact on the seed pathology of common bean cultivars. In the 2015-2016 harvest, in the city of Ipameri, Goiás, ten cultivars of common bean were evaluated (BRS Estilo ${ }^{\circ}$, BRS Pérola ${ }^{\oplus}$, IPR Tangará $^{\oplus}$, IPR Tuiuiú ${ }^{\odot}$, IPR Uirapuru ${ }^{\odot}$, IAC Milênio ${ }^{\oplus}$, Imperador ${ }^{\odot}$, IAC F3 R2 ${ }^{\odot}$, IAC OTG ${ }^{\odot}$ and IPR Campos Gerais $^{\odot}$ ) and distributed into five blocks, totaling 40 experimental units. The incidence of wilt and base rot and sanitary severity were analyzed by taking ten random samples per block at $21,28,56,63$ and 69 days after planting. At the end of 120 days, a total of 20 plants were harvested per cultivar, and 250 seeds were harvested for application of the Blotter Test method. From 21 to 69 days after planting, the cultivars BRS Pérola ${ }^{\odot}$ and IPR Campos Gerais ${ }^{\odot}$ deserve to be highlighted for presenting the lowest incidence of wilt in the reproductive and vegetative cycles. The cultivar BRS Pérola ${ }^{\circledR}$ showed the lowest incidence of wilt and sanitary severity. In the analysis of harvested seeds, the cultivar BRS Pérola ${ }^{\oplus}$ presented high physiological quality for all evaluated parameters. On the other hand, Cramberry $(\mathrm{OTG})^{\odot}$ showed low physiological potential in germination and vigor tests.
\end{abstract}

KEYWORDS: plant sanitary complex; wilt stem beans; Phaseolus vulgaris; genetic resistance; seed pathology.
RESUMO: O objetivo deste trabalho foi realizar uma avaliação temporal da incidência de podridáo-do-colo e severidade fitossanitária, e relacionar o impacto na patologia de sementes de cultivares comerciais de feijoeiro-comum. Na safra 2015-2016, no município de Ipameri, Goiás, foram avaliados dez cultivares de feijoeiro (BRS Estilo ${ }^{\odot}$, BRS Pérola $^{\odot}$, IPR Tangará $^{\odot}$, IPR Tuiuiú $^{\odot}$, IPR Uirapuru $^{\odot}$, IAC Milênio $^{\odot}$, Imperador $^{\odot}$, IAC F3 R2 ${ }^{\odot}$, IAC OTG ${ }^{\odot}$ e IPR Campos Gerais ${ }^{\odot}$ ), distribuídos em cinco blocos, totalizando 40 unidades experimentais. Analisou-se temporalmente a incidência da murcha e podridão-do-colo e a severidade fitossanitária tomando dez amostragens aleatórias por bloco aos 21, 28, 56, 63 e 69 dias após o plantio. Ao final dos 120 dias, colheu-se um total de 20 plantas por cultivar, sendo extraídas 250 sementes de cada para aplicação do método "Blotter Test". Dos 21 aos 69 dias após o plantio, merecem destaque os cultivares BRS Pérola ${ }^{\odot}$ e IPR Campos Gerais ${ }^{\odot}$, por apresentarem as menores incidências de murcha nos ciclos reprodutivo e vegetativo. O cultivar BRS Pérola $^{\oplus}$ apresentou as menores incidências de murchas e severidade fitossanitária. $\mathrm{Na}$ análise de sementes colhidas, o cultivar BRS Pérola ${ }^{\odot}$ apresentou elevada qualidade fisiológica para todos os parâmetros avaliados. Em contrapartida, o cultivar Cramberry $(\mathrm{OTG})^{\odot}$ mostrou baixo potencial fisiológico nos testes de germinação e vigor.

PALAVRAS-CHAVE: complexo fitossanitário; murcha vascular; Phaseolus vulgaris; resistência genética; patologia de sementes. 


\section{INTRODUCTION}

The common bean (Phaseolus vulgaris L. - Fabaceae) is cultivated by small and large growers, in different production systems and in all Brazilian regions, having great economic and social importance (AIDAR et al., 2003). It is recognized as a subsistence crop in small farms, but in recent years there has been increasing interest from producers in other classes, adopting advanced technologies which include irrigation and mechanized harvesting. In the 2014/2015 crop, common bean production accounted for $69.2 \%$ of the volume produced and was evenly distributed in the three annual harvests (CONAB, 2015).

The symptoms of base rot can often result in etiologic plasticity and irreversible damage in the field. The fusariumwilt is an important disease caused by a parasitic fungus that economically affects important species in the world, such as cotton, bananas, tomatoes, legumes and flowers. This pathogen was first identified infecting common bean in 1929 in the USA, and since then the species has been characterized as being Fusarium oxysporum f. sp. phaseoli (Fop). It penetrates the root tissues, and subsequently colonizes the vascular tissues, causing blockage of the phloem vessels, vascular discoloration and total wilt of the plant (XUE et al., 2015). The graybean rot caused by Macrophomina phaseolina produce dark lesions in the epicotyls and hypocotyls of seedlings, provoking deaths in the pre and post emergence due to obstruction of the xylem and wilting vessels. In adult plants it causes root lesions of annular color, varying from red to brown, and produces dark to black mycelium, replete with microsclerotia. The stem presents through black longitudinal cracks that lead to defoliation and wilt (ABAWI; PASTOR-CORRALES, 1990).

NEEGARD (1977) pointed out that seeds with lower physiological properties are susceptible to greater degradation and infection by plant pathogens from the field before harvest, and in the soil at the time of planting, the same opposite idea is equivalent to those with better physiological properties. Approximately $90 \%$ of the cultures used in the feeding are propagated by seeds, among them the beans that can be affected by devastating pathogens transmitted through seeds. The inoculum present in the seed may result in a progressive increase of a given disease in the field (HENNING, 2005).

Many of the pathogens that cause diseases in common bean, if not all, can be transmitted and transported by the seeds. In this way, they are important vehicles for the dissemination or introduction of pathogens in an area. Contaminated bean seeds may introduce pathogens that do not yet exist in a region, or introduce a race of a pathogen that causes considerable crop damage (ITO et al., 2003).

In addition, it is important to note that there are several studies that consider the activity of complexes of biotic and abiotic agents during the bean cycle, interfering with important physiological and productive activities (PAZ LIMA et al., 2016). One of the strategies refers to the use of multivariate analyzes and consider the multiple agents in studies of bean varietal behavior.

The objective of this work was to conduct a temporal evaluation of the incidence of base rot/wilt and sanitary severity and influence about seed pathology of common bean commercial cultivars.

\section{MATERIAL AND METHODS}

The experiment was carried out in the agricultural year of 2016/2017, at the RC Cruz Experiment Station, Fazenda Esmeralda, highway BR 050, latitude: $17^{\circ} 29^{\prime} 31.35^{\prime \prime}$, longitude: $48^{\circ} 12^{\prime} 56.93^{\prime \prime}$, altitude: $908 \mathrm{~m}$, in the city of Ipameri, GO. The soil was characterized as dystrophic red-yellow latosol.

Planting was performed on November 20, 2016, represented by ten bean cultivars (Cramberry $\mathrm{IPR}^{\odot}$, Imperador ${ }^{\odot}$,

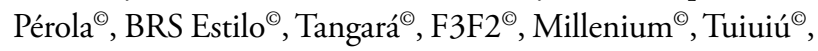
Uirapuru $^{\odot}$ and Campos Gerais ${ }^{\odot}$ ), in different stages between 75 to 120 days, cultivated in four blocks, totaling 40 experimental units (EU). Each plot had the dimensions of $4 \times 9 \mathrm{~m}$, row spacing of $0.5 \mathrm{~m}$ of the lines (eight cultivation lines), with an area of $36 \mathrm{~m}^{2}$ per plot, and scattered $0.5 \mathrm{~m}$ from the ends of the plots forming a useful area of $24 \mathrm{~m}^{2}$.

\section{Incidence and sanitary severity of common bean cultivars}

In each block, it was measured the incidence of bean wilt and base rot [period of 21, 28, 56, 63 and 69 days after planting (DAP)], and of sanitary severity (period of 53, 63 and $69 \mathrm{DAP}$ ). The result was obtained by the calculation of the number of plants showing symptoms of base rot or wilt divided by the total of the ten plants evaluated - this proportion being randomly assessed ten times in each plot on different days. The sanitary severity was performed using an adapted severity scale (AZEVEDO, 1998). The percentage of area with sanitary damage that is represented by biotic (pest and disease) and abiotic damages in ten leaves per plot on different days of evaluation was identified (AZEVEDO, 1998) for the phytosanitary severity of common bean.

The area under the disease progress curve (AUDPC) was calculated by integrating the disease progress curve for each treatment (incidence and sanitary severity $\mathrm{x}$ days), using the Equation 1:

$\mathrm{AUDCP}=\sum_{i}^{n-1} \frac{\left(X_{i}+X_{i+1}\right)\left(t_{i+1}-t_{i}\right)}{2}$

Where:

$\mathrm{n}$ is the number of severity evaluations,

$\mathrm{X}_{\mathrm{i}}$ is the incidence an /or sanitary severity;

$t_{i+1}-t_{i}$ is the number in days between consecutive evaluations (CAMPBELL; MADDEN, 1990). 
The value of the AUDCP synthesized all the evaluations of incidence and/or sanitary severity in a single value. The infection rate (IR) was achieved by calculating the regression coefficient in the period between the evaluation days (X - DAP) with the incidence and/or sanitary severity $(\mathrm{Y})$, obtaining the measurements of each one of repetitions. The measures of incidence of wilt or base rot and sanitary severity were plotted in order to construct progress curves. The common bean cultivars were identified according to the reaction types based on the AUDCP means.

\section{Pathology of seeds of commercial soybeans cultivars}

Seed collection occurred at 120 DAP in the experimental area of commercial bean cultivars. Twenty plants representing each block were randomly collected, and the seeds were separated from the pods.

The physiological activity of the seeds was evaluated by the water content (WC), determined by the oven method at $105 \pm 3^{\circ} \mathrm{C}$ for 24 hours (BRASIL, 2009), using two replicates with 50 grams each. The results were expressed as percentages and were calculated based on the wet mass $(\mathrm{Bu})$. For the germination test (\%), four replicates of 50 seeds arranged in rolls of paper were used, moistened with distilled water in an amount corresponding to 2.5 times the mass of the dry paper. The rolls were maintained in a germinator regulated at $25^{\circ} \mathrm{C}$ for nine days, and the results were expressed as percentage of normal seedlings. The first count was performed along with the germination test, counting the normal seedlings present on the fifth day after sowing. The accelerated aging was carried out with four sub-samples of 200 seeds for each treatment, using the Gerbox method, where 200 seeds were placed on the stainless-steel screen of a plastic box (Gerbox) with $40 \mathrm{~mL}$ of distilled water. After placing the lid, the boxes were taken to the germinator set at $41\left( \pm 0.5^{\circ} \mathrm{C}\right)$, where they remained for 48 hours. After this period, the seeds were evaluated for germination and the results were expressed as a percentage.

All dependent variables from the field trial and seed analysis in the laboratory were submitted to parametric hypothesis tests (F test), with averages compared by the Tukey test at 5\% probability and non-parametric test (Friedmann test), with means compared by the test Skot-Knott at 5\% probability using the R program. All dependent variables were subjected to multivariate analysis using the main component method of program $\mathrm{R}$.

\section{RESULTS AND DISCUSSION}

\section{Incidence and sanitary severity by common bean cultivars}

Through isolation in the culture medium, the soil diseases identified (Table 1) had two causal agents of vascular wilts, yellowing and rot of the colon represented by Fusarium oxysporum f.sp. phaseoli (samples collected at 21 DAP) and in the reproductive stage Macrophomina phaseolina (69 DAP) (ESTRELA et al., 2016). Among the main causative agents of vascular wilts, yellowing and base rot, BEDENDO (2011) emphasized the etiology and frequency of these two identified plant pathogens. One of the strategies of reduction of these

Table 1. Transformed averages $(X+10)$ of incidence of wilted and rotting base (\%) on different DAP, AUDCP, GR, \% day $\left.{ }^{-1}\right)$ and reaction types in different bean cultivars grown in the 2015-2016 harvest.

\begin{tabular}{|c|c|c|c|c|c|c|c|c|c|c|c|c|c|c|c|}
\hline \multirow{3}{*}{$\begin{array}{l}\text { Common Beans } \\
\text { cultivars } \\
\text { 1. BRS Estilo }\end{array}$} & \multicolumn{10}{|c|}{ Incidence (\%)* } & \multirow{2}{*}{\multicolumn{2}{|c|}{ AUDCP* }} & \multirow{2}{*}{\multicolumn{2}{|c|}{$\mathbf{I R}^{*}$}} & \multirow{2}{*}{$\begin{array}{l}\text { Reaction } \\
\text { Types** }\end{array}$} \\
\hline & \multicolumn{2}{|c|}{21 DAP } & \multicolumn{2}{|c|}{28 DAP } & \multicolumn{2}{|c|}{56 DAP } & \multicolumn{2}{|c|}{63 DAP } & \multicolumn{2}{|c|}{69 DAP } & & & & & \\
\hline & 5.0 & $b$ & 5.0 & a & 0.0 & c & 4.5 & $b$ & 4,5 & a & 147,7 & $a b$ & $-0,0550$ & $\mathrm{~cd}$ & Susceptible \\
\hline 2. BRS Pérola & 3.3 & c & 1.0 & $b$ & 1.2 & c & 3.0 & c & 3,0 & $b$ & 78,4 & $c d$ & 0,0350 & $a b$ & Resistance \\
\hline 3. IPR Tangará & 5.0 & $b$ & 1.5 & $b$ & 4.7 & a & 1.5 & c & 1,5 & $b$ & 141,1 & $a b$ & $-0,0100$ & $b c$ & Susceptible \\
\hline 4. IPR Tuiuiú & 3.7 & c & 2.5 & a & 2.1 & $b$ & 2.0 & c & 2,0 & $\mathrm{~b}$ & 112,4 & bc & $-0,0050$ & $b c$ & Susceptible \\
\hline 5. IPR Uirapurú & 5.0 & $b$ & 2.5 & a & 3.1 & $b$ & 1.5 & c & 3,0 & $b$ & 142,1 & $a b$ & $-0,0650$ & $\mathrm{~cd}$ & Susceptible \\
\hline 6. IAC Milênio & 10.0 & a & 3.0 & a & 1.1 & c & 4.0 & b & 4,0 & a & 137,5 & $a b$ & $-0,0350$ & bc & Susceptible \\
\hline 7. Imperador & 5.0 & $b$ & 5.0 & a & 2.1 & b & 0.5 & c & 0,5 & b & 152,6 & a & $-0,1400$ & $d$ & Susceptible \\
\hline 8. IAC F3 R2 & 10.0 & a & 1.0 & $b$ & 0.0 & c & 1.0 & c & 1,0 & $b$ & 57,9 & $\mathrm{~cd}$ & $-0,0900$ & $c d$ & Resistance \\
\hline 9. IAC OTG & 6.7 & $b$ & 0.0 & b & 2.1 & $b$ & 8.5 & a & 8,0 & a & 139,4 & $a b$ & 0,0750 & $a$ & Susceptible \\
\hline 10. IPR Campos Gerais & 6.7 & $b$ & 0.5 & $b$ & 0.0 & c & 0.0 & c & 0,0 & $b$ & 24,0 & $d$ & $-0,0700$ & $\mathrm{~cd}$ & Resistance \\
\hline Valeu $F_{9,190}$ & 9.168 & & 2.39 & & 6.94 & & 3.23 & & 2.59 & & 36.56 & & 50.129 & & \\
\hline Variation Coeficient & 10.5 & & 17.6 & & 10.3 & & 19. & & 21 & & 35. & & 36.0 & & \\
\hline
\end{tabular}

*Averages followed by the same vertical letters do not differ from eachother to the Skott-Knott and Tukey test at $p \sim 0.05$; ** The reaction types were pointed based on the AUDCP means. 
withered ones in the field is the genetic resistance, a low-cost technology that decreases the environmental impact by the nonuse of agricultural pesticides (CÂNDIDA et al., 2009).

The highest incidences of the disease were variable on the different days evaluated, reaching a range of $0-10 \%$ of symptoms in the assessed area (Table 1). At 21 DAP, the cultivars BRS Pérola ${ }^{\oplus}$ and IPR Tuiuiú ${ }^{\oplus}$ presented statistically the lowest incidence of symptoms of the disease (colic rot, wilt and yellowing). At 28 DAP, cultivar BRS Pérola ${ }^{\circledR}$ continued to stand out, alongside IPR Tangará, IAC F3 F2 ${ }^{\odot}$, IAC OTG ${ }^{\odot}$ and IPR Campos Gerais $^{\odot}$ for statistically presenting the lowest incidence (resistance) of the disease. At 56 DAP, after three evaluations, the cultivar BRS Pérola ${ }^{\oplus}$ continued to stand out, now along with BRS Estilo ${ }^{\oplus}$, IAC Milênio ${ }^{\oplus}$, IAC F3 R2 ${ }^{\odot}$ and IPR Campos Gerais ${ }^{\ominus}$ for statistically presenting the lowest incidence (resistance) of the disease.

At 63 DAP, after four evaluations, the cultivar BRS Pérola ${ }^{\oplus}$ continued to stand out, now with IPR Tangará ${ }^{\oplus}$, IPR Tuiuiú $^{\oplus}$, IPR Uirapuru $^{\oplus}$, Imperador ${ }^{\odot}$, IAC F3 R2 ${ }^{\odot}$ and IPR Campos Gerais ${ }^{\odot}$ for statistically presenting the lowest incidence (resistance) of the disease. Commercially described in the portfolio of cultivars, Imperador ${ }^{\odot}$ cultivar, in addition to maintaining resistance to anthracnose, bacteriosis and fusarium wilt (Fusarium oxysporum) presents precocity, with a cycle of 75 days, considering the sowing phase at harvest (IAC 2018).

And finally, at 69 DAP, most of the cultivars presented a statistically lower incidence of the disease, except BRS Estilo $^{\odot}$, IAC Milênio ${ }^{\odot}$ and IAC OTG ${ }^{\odot}$. From 21 to 69 DAP, the cultivars BRS Pérola ${ }^{\odot}$ and IPR Campos Gerais ${ }^{\odot}$ deserve special mention because they presented statistically the smallest means of wilt incidence (resistance), both in the reproductive and in the vegetative cycle. However, the cultivar IAC Milênio ${ }^{\circ}$ deserves special attention because it presents statistically the highest averages of disease incidence (Susceptibility) during the cycle. IAC OTG ${ }^{\odot}$ showed the highest growth rate (GR, \% / day), being IPR Campos Gerais ${ }^{\odot}$ the cultivar with the lowest rate (Table 1). Instead of evaluating genotypes, CÂNDIDA et al. (2009) recognized the $12 \mathrm{DAP}$, bean lines from crosses Milhionário $1732^{\circ} \mathrm{x}$ Macanudo $^{\odot}$ and FT-Tarumã ${ }^{\odot}$ x Macanudo ${ }^{\odot}$. concluding that the inheritance of resistance to fusarium wilt was oligogenic with genetic effect (additive genetic variance). It was greater than the environmental due to heritability cultivars, valuing the durable and stable resistance of cultivars. RAVA et al. (1996) recognized IAPAR $44^{\circ}$, Millionário $1732^{\circ}$, FT Tarumã $^{\oplus}$, Serrano ${ }^{\oplus}$, São José ${ }^{\oplus}$ and Rico $1735^{\circ}$, cultivars not tested in this work, as resistant to fusarium wilt in different Brazilian cultivation regions, as well as the cultivar Pérola $^{\odot}$ identified in this paper. Although Fusarium oxysporum f.sp. phaseoli presented little genetic variability (CÂNDIDA et al., 2009), the plant pathogen M. phaseolina showed wide morphological and genetic variability of isolates (many breeds) from Mexico (MAYÉK-PERES et al., 2001). In the field of production, resistant cultivars were harvested in mixed and dispersed infections (ESTRELA et al., 2016).

The high susceptibility of some evaluated bean cultivars can be explained by the selection of plants in the absence of the pathogen or resistance in the parents that gave rise to them (MARINGONI; LAURETTI, 1999). The source of resistance in studies of inheritance in Mexico from beans to $M$. phaseolina is found in BAT 477 (HERNANDEZ-DELGADO et al., 2009), a genotype not studied in this work.

During the growing cycle, the rate of growth of the disease ranged from $0.8 \%$ of wilt incidence (day 1 ) (cultivar) to $10.5 \%$ incidence of wilt.day ${ }^{-1}$, that is, possibly the rate of infection or growth ranged due to varietal difference or inoculum variation in the evaluated area (Table 1). This rate is reduced when the amount of inoculum of the soil is decreased by protecting the infection site, preventing the pathogen from infecting the root (SALES JUNIOR et al., 2005).

The reaction groups wilted, yellowing or base rot represented $50 \%$ of the cultivars classified as resistant and $50 \%$ classified as susceptible, and none of the cultivars showed no symptoms of the disease in the field (Table 1). This work highlights the reaction of resistance to multiple agents associated with the symptoms described above, as some studies by MARINGONI; LAURETE (1999), LIMA et al. (2005), ALZETE-MARIN et al. (2005), PAZ LIMA et al. (2016), ESTRELA et al. (2016), which act on the bean colon, as well as the resistance to $M$. phaseolina (CRUCIOL; COSTA, 2017) and F. oxysporum f.sp. phaseoli (XUE et al., 2015). It has been considered in literature that in both bean and soybean crops, M. phaseolina epidemics will become emerging and worrying in the production fields, and there is a need for the recognition of cultivars resistant to this important plant pathogen (BEDENDO, 2011).

The cultivar that showed the highest sanitary severity at $56 \mathrm{DAP}$ was IAC F3 R2 ${ }^{\circ}$. From the $63 \mathrm{DAP}$ on the cultivar IAC $\mathrm{OTG}^{\odot}$ presented the highest severity parameters (Table 2) and GR (\% / day). When evaluating AACCPD, the largest area of progression of severity was for the cultivar IAC OTG $^{\odot}$ (Fig. 1).

PEREIRA et al. (2008) have described that in order to obtain resistant strains, it is necessary to first identify sources of disease resistance; soon after, to carry out the crossing of promising cultivars to incorporate the resistance in susceptible recommended cultivars or to increase the resistance in the ones available; and finally, to select the resistant individuals in segregating populations.

When we consider complexes of organisms in this experiment that infect or parasitize the main photosynthetic organ of bean cultivars, it is worth mentioning BRS Pérola ${ }^{\odot}$ as it presents statistically the lowest sanitary severity (Table 2).

When evaluating, in Table 2, the sanitary severity, which are the damages caused by biotic agents (pests and diseases) and abiotic agents, at 56 DAP the lowest leaf severity was 
observed for cultivars BRS Pérola ${ }^{\odot}$, IPR Tuiuiú ${ }^{\oplus}$ and IPR Uirapuru $^{\odot}$. At 63 DAP, also, a lower sanitary severity was observed in BRS Pérola, accompanied by a larger number of cultivars, as IPR Tangará ${ }^{\circ}$, IPR Tuiuíu ${ }^{\odot}$, IPR Uirapuru ${ }^{\odot}$, IAC Milênio and IAC F2 R2. At 69 DAP, the lowest sanitary severity was observed in cultivars BRS Pérola ${ }^{\oplus}$, IPR Tangará ${ }^{\odot}$ and IPR Campos Gerais ${ }^{\odot}$.

The AUDCP and GR measurements indicated the IPR Campos $\mathrm{Gerais}^{\odot}$, as it presented a differential reaction of greater resistance to pest attack in diseases in the aerial system than in the root system (Fig. 1).

The values of AUDCP of sanitary severity in the three evaluated days allowed to recognize IPR Campos Gerais ${ }^{\odot}$, BRS Pérola $^{\odot}$, IPR Tangará ${ }^{\oplus}$, IPR Uirapuru ${ }^{\odot}$, and IAC Milênio ${ }^{\odot}$ as the cultivars with smaller area of injured tissue (Fig. 1A). As with AUDCP, the growth rate of sanitary severity was also statistically lower for the cultivars IPR Campos Gerais ${ }^{\circledR}$ (lower growth rate), IPR Tangará ${ }^{\oplus}$, IPR Uirapuru ${ }^{\odot}$ (higher growth rate) (Fig. 1B).

SALA et al. (2006) report that the study of the physiological variability of the pathogen is of great importance for a breeding program, since the existence of breeds of the pathogen assumes that a genotype identified as resistant in a growing region may or may not maintain this trait in another region. RIBEIRO; HAGEDORN (1979) observed similar pathogenicity of isolates from USA and Holland, which were different from Brazilian isolates. As for bean resistance, RIBEIRO; FERRAZ (1984) tested 51 cultivars and obtained 14 with high resistance index, and another ten showed moderate levels of resistance.

The AUDCP allowed to recognize the cultivar BRS Pérola $^{\odot}$ as it presented statistically the lowest mean AUDCP of the incidence of vascular wilt and AUDCP sanitary severity, showing that the resistance to both disturbances is probably controlled by the same gene in this cultivar (Table 1).
The rate of infection when comparing the vascular incidence with the sanitary severity was lower, ranging from $0-10 \%$ day $^{-1}$ for the first and $0-4 \%$ day $^{-1}$ for the second (Table 1, Fig. 1B).

CÂNDIDA et al. (2009), when evaluating the genetic control of fusarium wilt in common beans, describe that the ones selected for having a lower severity score will have a reduced number of lesions caused by the fungus in the leaf, resulting in a decrease in inoculum source and in the chance of dissemination of the disease. On the other hand, strict selection indexes decrease the genetic variability of the selected population, which is not advisable in a breeding program. Although fusarium wilt resistance is an important criterion to be considered in the development of common bean cultivars, other characteristics are also evaluated, hence the relevance of genetic variability.

When we observed the degree of correlation between the variables used to evaluate vascular wilt, yellowing and / or base rot, the dependent variables that most explained the differences between common bean cultivars were the incidence of wilt at 56 DAP (X56DAP), the area values below the disease progress curve (AACPD), the incidence of the disease at 69 DAP (X69DAP - major effect) and the incidence of the disease at 21 DAP (Fig. 2A). The cultivar 5 (IPR Uirapuru ${ }^{\circ}$ ) was the most influenced by the incidence of the disease at 69 DAP. The cultivars (6) IAC Milênio ${ }^{\oplus}$, (8) IAC F3 R2 ${ }^{\odot}$, (9) IAC OTG $^{\odot}$ and (10) IPR Campos Gerais ${ }^{\odot}$ were the most influenced by the incidence of wilt at $56 \mathrm{DAP}$, area below the disease progress curve, incidence of disease at 69 DAP and incidence of disease at 21 DAP (Fig. 2A). When we observed the degree of correlation between the variables used to evaluate sanitary severity, the dependent variables that most explained the differences among common bean cultivars were sanitary severity at 56 DAP (X56DAP - major effect), sanitary severity at 69 DAP (X69dap) and GR - small effect. The cultivars (2) BRS

Table 2. Transform average by $(x+10)$ of sanitary severity in DAP, in different common bean cultivars cultivated in 2015-2016.

\begin{tabular}{|c|c|c|c|c|c|c|}
\hline \multirow{2}{*}{$\begin{array}{l}\text { Common } \\
\text { bean cultivars }\end{array}$} & \multicolumn{6}{|c|}{ Sanitary Severity (\%) } \\
\hline & \multicolumn{2}{|l|}{56 DAP } & \multicolumn{2}{|l|}{63 DAP } & \multicolumn{2}{|c|}{69 DAP } \\
\hline 1. BRS Estilo ${ }^{\circ}$ & 10.7 & c & 33.8 & b & 33.8 & $b c$ \\
\hline 2. BRS Pérola ${ }^{\odot}$ & 4.5 & d & 16.7 & c & 16.7 & d \\
\hline 3. IPR Tangará ${ }^{\circ}$ & 11.7 & c & 13.7 & c & 13.3 & d \\
\hline 4. IPR Tuiuiú ${ }^{\circ}$ & 6.8 & d & 23.7 & c & 23.7 & $\mathrm{~cd}$ \\
\hline 5. IPR Uirapuru ${ }^{\odot}$ & 4.9 & d & 18.4 & c & 18.4 & $\mathrm{~cd}$ \\
\hline 6. IAC Milênio ${ }^{\odot}$ & 12.0 & c & 18.9 & c & 18.9 & $\mathrm{~cd}$ \\
\hline 7. Imperador ${ }^{\odot}$ & 17.7 & $b$ & 39.2 & $b$ & 39.2 & $b$ \\
\hline 8. IAC F3 R2 ${ }^{\circ}$ & 31.6 & a & 21.4 & c & 21.4 & $\mathrm{~cd}$ \\
\hline 9. IAC OTG $^{\circ}$ & 13.4 & c & 65.5 & $a$ & 65.5 & A \\
\hline 10. IPR Campos Gerais ${ }^{\odot}$ & 9.8 & c & 12.6 & c & 12.0 & $d$ \\
\hline F value & \multicolumn{2}{|c|}{$F_{9.190}=19.342^{* *}$} & \multicolumn{2}{|c|}{$F_{9.190}=18.409 * *$} & \multicolumn{2}{|c|}{$F_{9.160}=17.842^{* *}$} \\
\hline $\mathrm{CV}$ & 16.04 & & 21.6 & & 22.5 & \\
\hline
\end{tabular}

*Averages followed by the same vertical letters do not differ from each other to the Skott-Knott and Tukey test at $\mathrm{p} \sim 0.05$. 
Pérola ${ }^{\odot},(10) \mathrm{IPR}$ Campos Gerais ${ }^{\odot}$ and (9) $\mathrm{IAC} \mathrm{OTG}^{\odot}$ were the least influenced by sanitary severity at $56 \mathrm{DAP}$, sanitary severity at $69 \mathrm{DAP}$ and growth rate (Fig. 2B).

GOMES (2014) reported that M. phaseolina can infect bean plants at various stages of growth, and depending on the stage of the plant in which the infection starts, many components of crop yield may be affected. This fact was also verified in the experiment carried out by CRUCIOL; COSTA (2017), who observed that the diameter of the lap, leaf width, leaf length and number of leaves were also affected by $M$. phaseolina in different evaluation periods.

When we observed the degree of simultaneous correlation between the variables used to evaluate vascular wilt, yellowing

A
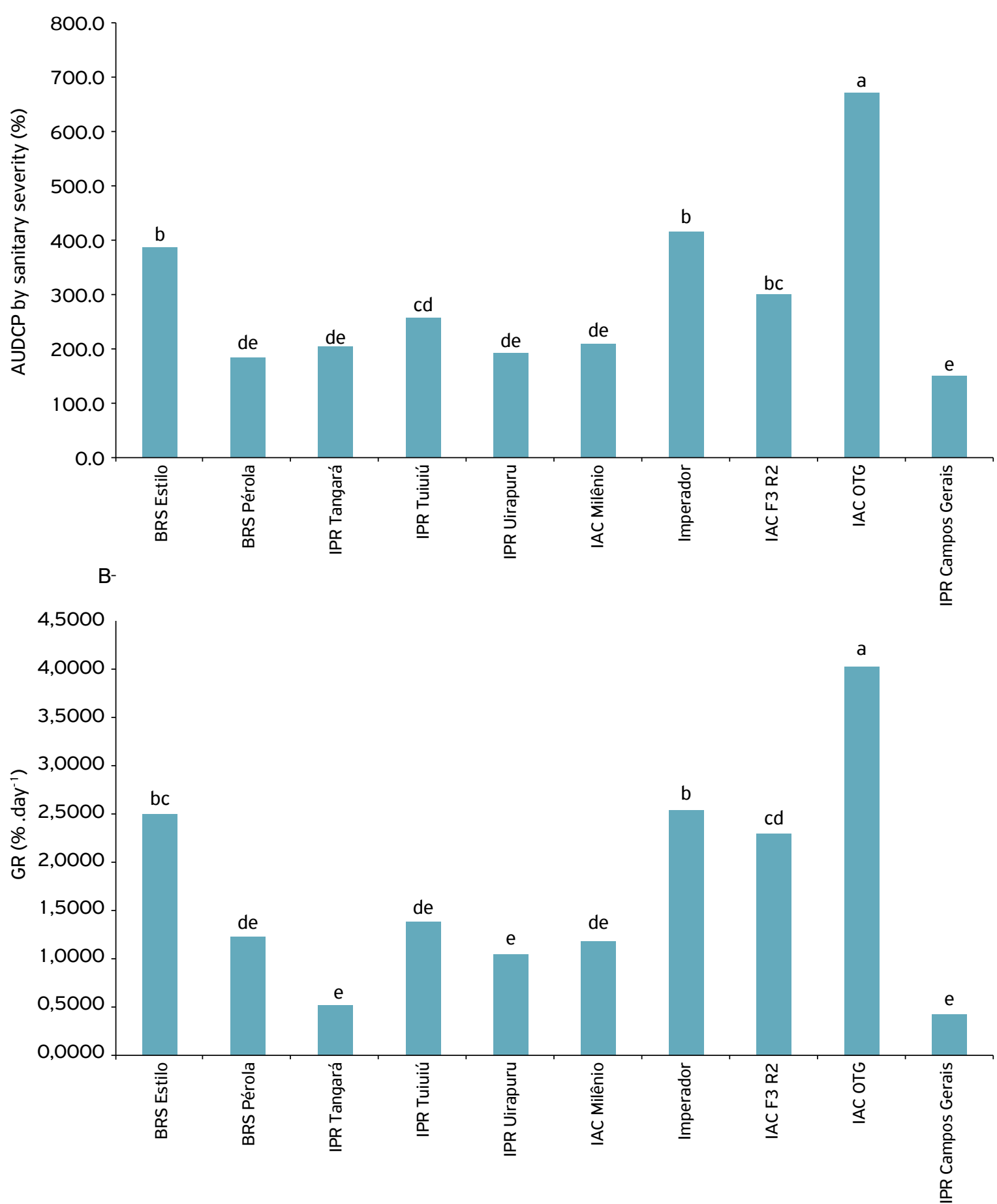

Figure 1. Epidemiological parameters obtained from sanitary severity in different commercial common bean cultivars. (A) AUDCP Area below the disease progress curve, (B) GR -Growth rate (\%.day $\left.{ }^{-1}\right)$; averages followed by the same vertical letters do not differ from each other to the Tukey test at $p \sim 0.05$. 
and / or base rot and sanitary severity, the dependent variables that most explained the differences between common bean cultivars were the averages of area values (AUDCP.I) as well as sanitary severity (AUDCP.S). The cultivars (5) IPR Uirapuru $^{\odot}$, (6) IAC Milênio ${ }^{\odot}$, (1) BRS Estilo ${ }^{\odot}$ and (3) IPR Tangará $^{\oplus}$ showed the least influence of the area below the wilt disease progression curve (AUDCP.I) and sanitary severity [AUDCP (Fig. 2C)]. Some measures can be adopted to control these diseases, especially in non-infested soils, as the use of healthy seeds, crop rotation, adequate use of irrigation and resistant cultivars. To obtain bean varieties with resistance to such pathogens, it is necessary to know the resistance levels present in several genotypes that could be used as resistance donor progenitors in crossing with susceptible materials. It is of interest to have bean genotypes with good levels of resistance to various pathogens, which considerably facilitate the incorporation of these genes into susceptible cultivars. In many cases the resistance level of bean genotypes to specific pathogens is known, but their behavior against other pathogens is unknown (MARINGONI; LAURETTI, 1999).
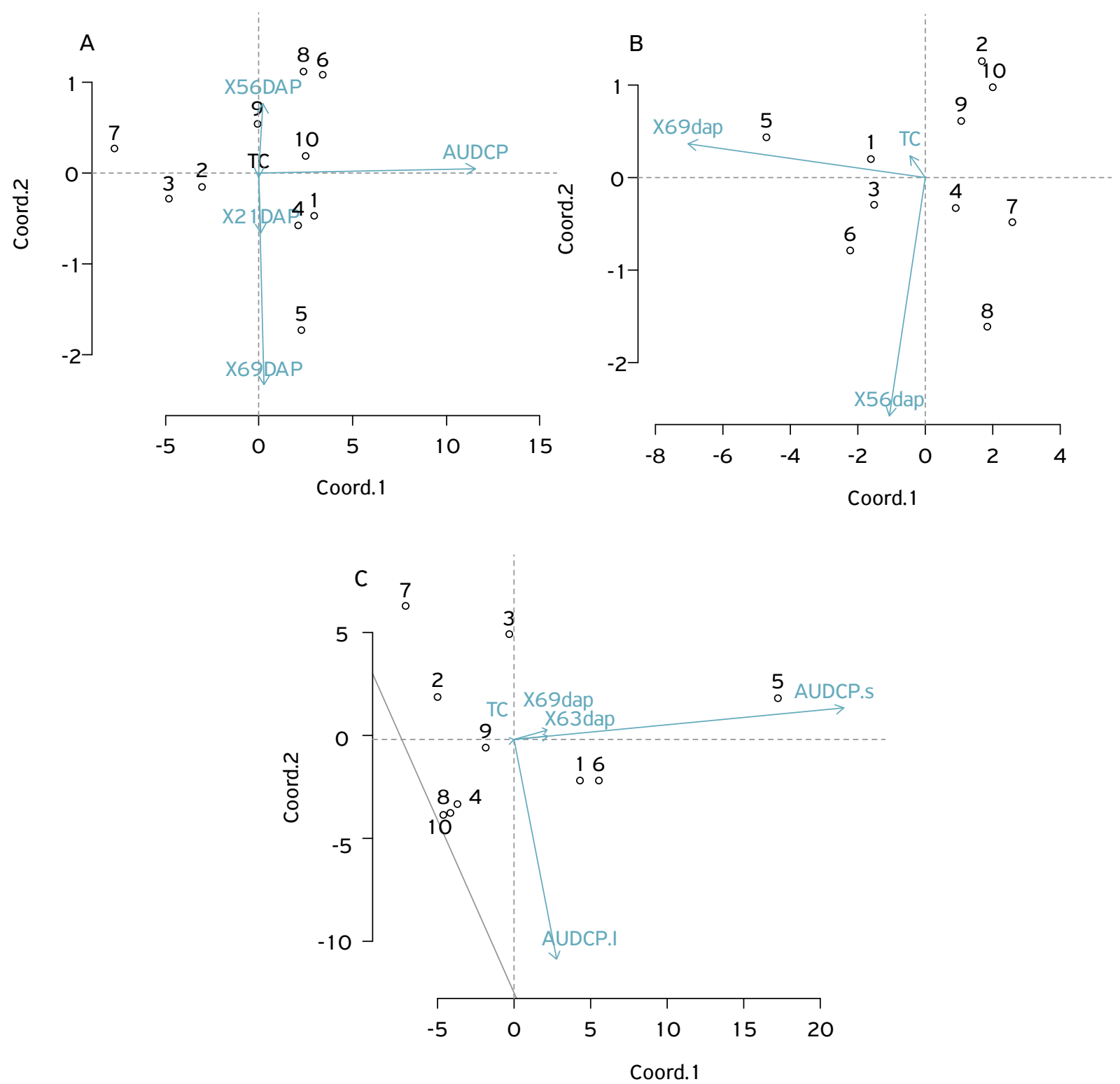

Figure 2. Main component of sanitary variables evaluated on common bean cultivars. (A) Incidence (\%) on different DAP; AUDCP.I: area under the disease curve progress; GR: growth rate; (B) Severity (\%) by DAP; AUDCP.S: area under the disease curve progress by severity sanitary; GR: growth rate by plant disease; (C) Interaction between dependent variables for cultivars ranking. 1 . BRS Estilo $^{\odot}$, 2. BRS Pérola ${ }^{\odot}$, 3. IPR Tangará ${ }^{\odot}$, 4. IPR Tuiuiú ${ }^{\circ}$, 5. IPR Uirapuru ${ }^{\odot}$, 6. IAC Milênio ${ }^{\odot}$, 7. Imperador ${ }^{\odot}$, 8. IAC F3 R2 ${ }^{\odot}$, 9. IAC OTG ${ }^{\odot}$ and 10. IPR Campos Gerais ${ }^{\odot}$. 


\section{Seed pathology by common bean cultivars}

The ANOVA-test rejected the hypothesis of nullity of five dependent physiological variables analyzed to differentiate bean cultivars (Table 3 ).

The highest value of moisture content was statistically similar among cultivars (Table 3).

Statistically the highest averages of $\%$ germination (PRE) were presented by the cultivars Pérol ${ }^{\odot}$, Uirapuru $^{\odot}, F 23^{\odot}$ and Campos Gerais ${ }^{\odot}$. The cultivars with the lowest mean germination percentage were BRS Estilo ${ }^{\odot}$, Cramberry $(\mathrm{OTG})^{\odot}$, Imperador ${ }^{\odot}$, Milênio $^{\oplus}$, Tangará ${ }^{\oplus}$ and Tuiuiư ${ }^{\oplus}$, differing from others (Table 3).

Regarding the first count (FC), statistically the highest average was observed for the cultivars Pérola ${ }^{\Theta}$, Tangará $^{\oplus}$ and BRS Estilo ${ }^{\odot}$. The cultivar Cramberry $(\mathrm{OTG})^{\odot}$ presented the lowest average of the first count (Table 3).

In relation to Accelerated Aging (AA), the highest averages were presented by the cultivars Pérola $^{\odot}$, Tangará $^{\oplus}$ and Campos Gerais $^{\odot}$ differing statistically from the others analyzed. Statistically the lowest accelerated aging was observed in the cultivar Cramberry $(\mathrm{OTG})^{\oplus}$ (Table 3). This fact can be explained due to the exposition to high humidity and temperature, therefore their germinative potential was not altered. MARCOS FILHO (2015) pointed out that lower germination values occurred due to aging, as well as lower seeds vigor and, consequently, a greater drop in viability. A different result was found by PINTO (2015) in the study that evaluated the performance of bean cultivars of the commercial group from Rio de Janeiro, where IAC Milênio ${ }^{\odot}$ showed the highest germination drop during storage from $91 \%$ to $66 \%$, respectively, and also presented low values in AA, from 57 to $44 \%$.

The bean cultivars that presented the best physiological activities were those that had the highest values in relation to the physiological criteria evaluated. In this way it can be said that the cultivar Pérola ${ }^{\circledast}$ presented the greatest physiological activity, standing out statistically against the evaluated criteria. Also, the cultivar Campos Gerais ${ }^{\odot}$ had the best physiological activity using different methods of seed analysis (Table 1). It is worth mentioning that the reaction in the field of cultivar Campos Gerais ${ }^{\circledR}$ is considered susceptible to fusarium wilt (Fusarium oxysporum), rust (Uromyces appendiculatus) and anthracnose (Colletotrichum lindemunthianum).

When analyzing the dependent variables together, the cultivar Uirapuru ${ }^{\oplus}$ deserves to be highlighted as it presents statistically the highest averages of PRE, WC and GS. The cultivar Uirapuru ${ }^{\odot}$ is considered susceptible to fusarium wilt (F. oxysporum), rust (U. appendiculatus) and anthracnose (C. lindemunthianum).

The cultivar Pérola ${ }^{\oplus}$ also presented statistically the highest averages of GS, FC and AA. It is important to note its super resistance to rust (U. appendiculatus) and fusarium wilt (F. oxysporum), and a lower incidence of diseases. Cramberry $(\mathrm{OTG})^{\odot}$ showed the lowest PRE, FC and AA averages (Table 3). NEERGARD (1977) pointed out that the seeds with the lowest physiological properties, such as those mentioned above, are susceptible to greater degradation and infection by field pathogens before harvest. At the time of planting, the same opposite idea is equivalent to those with better physiological properties.

The null hypothesis was rejected for the dependent variables INC \%, \% of Aspergillus flavus, \% of Penicillium sp., \% of Fusarium oxysporum, and \% of Macrophomina phaseolina, with no rejection for the dependent variable \% of Fusarium solani (Table 4).

The cultivars Uirapuru ${ }^{\odot}$ and Campos Gerais ${ }^{\odot}$, respectively, presented the lowest and highest mean of INC \% (Table 4), which represent the amplitudes of higher occurrence of

Table 3. Average of primary root emission ("Blotter Test”) (PRE). water content (WC). germination on substrate ("steril sand") (GS). first count (FC. \%) and accelerated aging (AA) of common bean commercial seeds harvested in 2015/2016.

\begin{tabular}{|c|c|c|c|c|c|c|}
\hline \multirow{2}{*}{$\begin{array}{l}\text { Common bean cultivars } \\
\text { Campos Gerais }^{\odot}\end{array}$} & \multicolumn{2}{|c|}{ PRE (\%) } & \multirow{2}{*}{$\begin{array}{c}\text { WC (\%) } \\
7.32\end{array}$} & \multirow{2}{*}{$\begin{array}{l}\text { GS (\%) } \\
91.5 \mathrm{ab}\end{array}$} & \multirow{2}{*}{$\begin{array}{l}\text { FC (\%) } \\
69.5 b c\end{array}$} & \multirow{2}{*}{$\begin{array}{l}\text { AA (\%) } \\
82.0 \mathrm{ab}\end{array}$} \\
\hline & 24.2 & a & & & & \\
\hline BRS Estilo $^{\odot}$ & 16.3 & d & 7.87 & $81.5 b c$ & $76.0 \mathrm{ab}$ & $60.0 \mathrm{de}$ \\
\hline OTG $^{\odot}$ & 19.1 & c & 7.54 & $74.0 \mathrm{c}$ & $21.5 d$ & $15.0 \mathrm{~g}$ \\
\hline $\mathrm{F}^{2} \mathrm{~F}^{\circ}{ }^{\circ}$ & 19.7 & c & 7.31 & $92.0 \mathrm{ab}$ & $57.0 \mathrm{bc}$ & $39.5 f$ \\
\hline Imperador ${ }^{\odot}$ & 18.8 & c & 7.72 & $76.0 \mathrm{bc}$ & $53.5 \mathrm{bc}$ & $36.5 f$ \\
\hline Milênio ${ }^{\odot}$ & 24.4 & $\mathrm{a}$ & 7.90 & $76.5 b c$ & $48.5 \mathrm{c}$ & $56.5 \mathrm{e}$ \\
\hline Pérola ${ }^{\odot}$ & 23.0 & $b$ & 7.90 & $96.5 \mathrm{a}$ & $91.5 \mathrm{a}$ & $89.5 \mathrm{a}$ \\
\hline Tangará ${ }^{\circ}$ & 23.1 & $\mathrm{~b}$ & 7.70 & $90.5 b c$ & $83.0 \mathrm{a}$ & $83.0 \mathrm{ab}$ \\
\hline Tuiuiú $^{\odot}$ & 24.3 & $\mathrm{a}$ & 7.80 & $84.0 \mathrm{bc}$ & $66.5 b c$ & $70.5 \mathrm{~cd}$ \\
\hline Uirapuru $^{\odot}$ & 24.8 & $\mathrm{a}$ & 8.11 & $91.0 \mathrm{ab}$ & $69.0 \mathrm{bc}$ & $75.0 \mathrm{bc}$ \\
\hline F Value & \multicolumn{2}{|c|}{$F 2.611=47.93^{* *}$} & nd & nd & nd & nd \\
\hline CV \% & \multicolumn{2}{|c|}{1.04} & nd & 8.00 & 16.70 & 7.25 \\
\hline
\end{tabular}

*Averages followed by the same vertical letters do not differ from each other to the Tukey test at at $p \sim 0.05$. 
microorganisms associated with the seeds. The others statistically presented their means located between these two commercial common bean cultivars.

There were differences between the INC \% averages associated with the analyzed seeds (Table 4). The highest INC \% associated with seeds of the commercial cultivars was observed in $\mathrm{F} 2 \mathrm{~F}^{\odot}{ }^{\odot}$, and the lowest incidence was observed in BRS Estilo ${ }^{\odot}$,

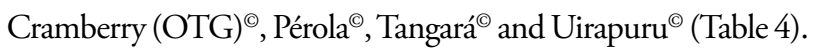
It is important to emphasize that these microorganisms associated with the characteristic of being parasitic or pathogenic require inoculation tests; a taxon is only considered pathogenic when it is classically recognized in culture and in specific literatures (KIMATI et al., 2005). The percentage of Aspergillus flavus and Penicillium sp., classically mycotoxigenic and storage fungi (NEEGARD, 1977), were statistically more frequent in the cultivars Campos Gerais ${ }^{\odot}$ and Pérola ${ }^{\odot}$ (only incidental in the first), differing from the others (Table 4).

Processing methods, as well as agronomic practices, do not eliminate or completely prevent mycotoxins in foods produced by the genus Penicillium sp., Aspergillus sp. and Fusarium spp. detected (Table 4). Thus, prevention and harvesting with low moisture content is the most efficient way to control the production of these alkaloids (PAULA JUNIOR et al., 2004).

As for the Penicillium fungus, it can be observed that the storage temperature of the cultivars may have contributed to its development in some cultivars, and in others the storage temperature of the cultivar seeds was $\pm 5^{\circ} \mathrm{C}$. As NEEGARD (1977) reports, the optimum temperature for the growth and development of most storage fungi lies between 28 and $35^{\circ} \mathrm{C}$, the maximum and the lowest being respectively $50-55^{\circ} \mathrm{C}$ and $0-5^{\circ} \mathrm{C}$.

BERGAMIM FILHO et al. (1995) stated that the damage caused by the species of Aspergillus sp. and Penicillium sp. are variables such as loss of germination, seed discolouration, seed mass heating and toxin production. The activity of fungi decays readily with the reduction of temperature, and some species of Aspergillus spp. can reach their population 10 to 20 times faster when the temperature is $15^{\circ} \mathrm{C}$ to $32^{\circ} \mathrm{C}$ (CARVALHO; VON PINHO, 1997).

Table 4. Transforms Averages $\sqrt{ }(X+10)$ by microorganism incidence (INC \%) and incidence by Aspergillus flavus, Penicillium sp., Fusarium oxysporum, Fusarium solani and Macrophomina phaseolina on beans cultivars*.

\begin{tabular}{|c|c|c|c|c|c|c|}
\hline \multirow{2}{*}{$\begin{array}{l}\text { Bean Cultivars } \\
\text { Campos Gerais }^{\odot}\end{array}$} & \multicolumn{2}{|c|}{ INC \% } & \multicolumn{2}{|c|}{$\%$ Aspergillus flavus } & \multicolumn{2}{|c|}{ \% Penicillium sp. } \\
\hline & 5.2 & $\mathrm{a}$ & 2.8 & a & 4.8 & a \\
\hline BRS Estilo ${ }^{\odot}$ & 1.2 & c & 0.0 & $b$ & 0.1 & c \\
\hline Cramberry (OTG) ${ }^{\odot}$ & 1.2 & c & 0.3 & $b$ & 0.1 & c \\
\hline $\mathrm{F} 2 \mathrm{~F}^{\circ}$ & 0.7 & c & 0.5 & $b$ & 0.7 & c \\
\hline Imperador ${ }^{\odot}$ & 0.7 & c & 0.1 & $b$ & 0.4 & c \\
\hline Milênio ${ }^{\circ}$ & 2.6 & $b$ & 0.2 & $b$ & 1.4 & $b$ \\
\hline Pérola ${ }^{\odot}$ & 2.8 & $b$ & 2.2 & a & 1.9 & $b$ \\
\hline Tangará ${ }^{\circ}$ & 2.0 & $b$ & 0.0 & $b$ & 0.6 & c \\
\hline Tuiuiú $^{\odot}$ & 1.7 & $b$ & 0.0 & $b$ & 0.1 & c \\
\hline Uirapuru $^{\odot}$ & 0.0 & $d$ & 0.0 & $b$ & 0.0 & c \\
\hline Value F & \multicolumn{2}{|c|}{$\mathrm{F}_{2.611}=9.37^{* *}$} & \multicolumn{2}{|c|}{$\mathrm{F}_{2.611}=17.73^{* *}$} & \multicolumn{2}{|c|}{$F_{2.611}=11.84^{* *}$} \\
\hline CV \% & \multicolumn{2}{|l|}{5.69} & \multicolumn{2}{|c|}{4.14} & \multicolumn{2}{|c|}{5.52} \\
\hline Bean Cultivars (Cont.) & \multicolumn{2}{|c|}{ \% Fusarium oxysporum } & \multicolumn{2}{|c|}{$\%$ F. solani } & \multicolumn{2}{|c|}{$\%$ Macrophomina phaseolina } \\
\hline Campos Gerais $^{\odot}$ & 0.2 & $b$ & 0.3 & a & 0.0 & $b$ \\
\hline BRS Estilo ${ }^{\odot}$ & 0.3 & $\mathrm{a}$ & 0.8 & a & 0.1 & $b$ \\
\hline Cramberry (ОTG) ${ }^{\odot}$ & 0.7 & a & 0.1 & a & 0.1 & b \\
\hline $\mathrm{F} 2 \mathrm{~F}^{\circ}{ }^{\circ}$ & 0.0 & $b$ & 0.0 & a & 0.0 & b \\
\hline Imperador $^{\odot}$ & 0.0 & $b$ & 0.1 & $\mathrm{a}$ & 0.4 & $b$ \\
\hline Milênio ${ }^{\odot}$ & 0.7 & a & 0.7 & a & 0.3 & $b$ \\
\hline Pérola ${ }^{\odot}$ & 0.0 & $b$ & 0.2 & $a$ & 0.0 & $b$ \\
\hline Tangará ${ }^{\circ}$ & 0.3 & $\mathrm{~b}$ & 0.3 & a & 1.2 & a \\
\hline Tuiuiú ${ }^{\odot}$ & 0.8 & a & 0.6 & a & 0.2 & b \\
\hline Uirapuru $^{\odot}$ & 0.0 & $b$ & 0.0 & $a$ & 0.0 & $b$ \\
\hline Value $\mathrm{F}$ & $\mathrm{F}_{2.611}=$ & & $\mathrm{F}_{2.611}=$ & & $F_{2.611}$ & \\
\hline CV \% & 4.65 & & 4.89 & & 4.08 & \\
\hline
\end{tabular}

*Averages followed by the same vertical letters do not differ from each other to the Skott-Knott Test at $\mathrm{p} \sim 0.05$. 
The control is based on care during the harvesting operations, on the cleaning and drying of the grains and on the sanitization of bulk carriers, silos and mechanical equipment. Harvesting as soon as the ideal moisture content is reached also helps to prevent the development of fungi and the consequent production of toxins (BIANCHINI et al., 2005).

In relation to $\%$ of $F$ oxysporum, a more diversified species of the genus, an important decompositor associated to cultural residues and vascular plant pathogen, the cultivars BRS Estilo $^{\oplus}$, Cramberry $(\mathrm{OTG})^{\odot}$, Milênio ${ }^{\oplus}$ and Tuiuiú ${ }^{\odot}$ presented statistically the highest incidence (Table 4). BRS Estilo ${ }^{\odot}$ and Tuiuiú $^{\oplus}$ are highly susceptible in the field to $F$. oxysporum, thus proving the plant's transmissibility to the seeds. With regard to the $F$ solani, another species causing vascular wilts which belongs to a complex associated with fusarium wilt in bean, there was no significant difference between the means of its incidence on cultivar seeds (Table 4).

As for the incidence of Macrophomina phaseolina, which is an important pathogen that causes charcoal rot in, in addition to tipping in pre- and post-emergence beans (BIANCHINI et al., 2005), it was noted a difference between the average of the analyzed cultivars, being the highest incidence in Tangará ${ }^{\circ}$ (Table 4). Therefore, every 100 seeds of the cultivar Tangará ${ }^{\oplus}$ planted with 1 or 2 seedlings will present symptoms of this plant pathogen. This is a direct damage to the crop, and an inoculum distribution in the area in the later off-season, increasing its destructive power (BEBENDO, 2011). There was no incidence of $M$. phaseolina inCampos Gerais $^{\odot}, \mathrm{F}^{\mathrm{F}} 3^{\odot}$, Pérola $^{\odot}$ and Uirapuru ${ }^{\odot}$, revealing the tolerance of these cultivars regarding the incidence of M. phaseolina (Table 4).

The bean cultivar that statistically manifested the greatest amount of fungus genera was Campos Gerais ${ }^{\odot}$ (Table 4). Therefore, it was the cultivar with greater transmissibility of the species of genus of fungi.

Except for the incidence of $M$. phaseolina discussed above, the other cultivars presented satisfactory sanitation conditions. The different cycles of cultivars and genetic load influence the incidence of plant pathogens (NEEGARD, 1971).

Some of these fungi, although of common occurrence, are not considered important, as they originate diseases of little gravity from the economic point of view. However, it should be noted that other fungi, such as $F$ oxysporum, F solani, Colletotrichum capsici, C. truncatum (causal agents of the coffee stain) and Colletotrichum lindemuthianum (anthracnose), may cause severe damage to the crop (BIANCHINI et al., 2005).

The anthracnose, prompted by the fungus C. lindemunthianum, which was not detected in the seeds, is one of the most important diseases of the bean crop, affecting susceptible cultivars established in places with moderate to cold temperatures and high humidity worldwide. Possibly due to the predominance of hot and humid temperatures in the Midwest (Ipameri, GO), the pathogen was not detected in the evaluated seeds. In Brazil, this disease occurs in the main producing states and losses can be of the order of $100 \%$, when infected seeds are sown and the environment conditions are favorable to them (RAVA et al., 1994).

In the field the cultivar Imperador ${ }^{\circ}$ maintained resistance to anthracnose, bacteriosis and wilt of Fusarium oxysporum, and presents precocity, with a cycle of 75 days, considering the sowing phase at harvest. The cultivar BRS Estilo ${ }^{\odot}$ is highly susceptible to Fusarium oxysporum, rust, bacteriosis, angular spot and bean golden mosaic, and it does not tolerate $F$ solani. And the cultivars Tangará ${ }^{\oplus}$, Campos Gerais ${ }^{\odot}$, Tuiuiư $^{\odot}$ and Uirapuru $^{\odot}$ are susceptible to $F$ oxysporum, rust and anthracnose. The cultivar Pérola ${ }^{\odot}$ presents a reaction in the field of resistance to rust and the common mosaic. Under field conditions, it is moderately resistant to fusarium wilt and angular blight.

\section{CONCLUSION}

The cultivars BRS Pérola ${ }^{\oplus}$, IPR Tangará ${ }^{\oplus}$, IPR Tuiuiú ${ }^{\oplus}$ and IPR Uirapuru ${ }^{\odot}$ presented a lower incidence of the disease.

The cultivars IPR Campos Gerais ${ }^{\oplus}$, BRS Pérola ${ }^{\odot}$, IPR Tangará $^{\oplus}$, IPR Uirapuru ${ }^{\oplus}$ and IAC Milênio ${ }^{\oplus}$ presented a lower area of tissue damaged by biotic and abiotic agents.

Based on the parametric tests, the cultivar BRS Pérola ${ }^{\odot}$ was more resistant to the incidence of vascular wilt and foliar stains by biotic and abiotic agents.

The germplasm Aspergillus flavus, Penicillium sp., Fusarium solani, Fusarium oxysporum and Macrophomina phaseolina were identified.

The cultivar Pérola ${ }^{\circledR}$ presented high physiological quality for all evaluated parameters. On the other hand, Cramberry $(\mathrm{OTG})^{\odot}$ showed low physiological potential in germination and vigor tests. The cultivars Cramberry $(\mathrm{OTG})^{\odot}$ and Campos Gerais $^{\odot}$ showed the lowest and highest incidence of pathogens, respectively.

The fungi Aspergillus flavus and Penicillium sp. showed greater variability of fungi genus occurrence in the cultivars in relation to the other taxonomic category.

It was not possible to identify the relationship between the physiological and sanitary quality of the evaluated lots. But the identification of cultivars that genetically present the highest incidence and occurrence of associated plant pathogenic fungi represent an important epidemiological information that relates the genetic reaction of the cultivar with the transmissibility to plant pathogens. 


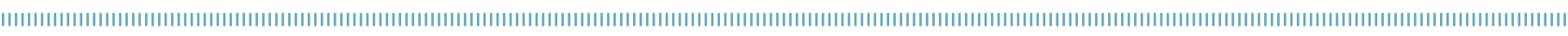
REFERENCES

ABAWI, G. S.; PASTOR-CORRALES, M. A. Root Rots of Beans in Latin America and Africa: Diagnosis, Research Methodologies, and Management Strategies. Cali, Colômbia, CIAT, 1990.

AIDAR, H.; KLUTHCOUSKI, J.; SANTOS, A. B.; THUNG, M. Recomendações técnicas para o cultivo do feijoeiro comum em várzeas tropicais irrigadas por subirrigação. Santo Antônio de Goiás: Embrapa Arroz e Feijão, 2003. Available from: <https:// www.agencia.cnptia.embrapa.br/recursos/circ_6OID-cRtyuL7Uwc. pdf >. Accessed on: Jan. 172018.

ALZETE-MARIN, A. L.; CERVIGNI, G. D. L.; MOREIRA, M. A.; BARROS, E. G. Seleção assistida por marcadores moleculares visando ao desenvolvimento de plantas resistentes a doenças, com ênfase em feijoeiro e soja. Fitopatologia Brasileira, v.30, n.4, p.333-342, 2005.

AZEVEDO, L. A. S. Manual de quantificação de doenças de plantas. São Paulo: Novartis, 1998. 114p.

BEDENDO, I. P. Podridões de raiz e colo. In: AMORIM, L.; REZENDE, J. A. M.; BERGAMIN FILHO, A. (Eds.). Manual de fitopatologia: princípios e conceitos. São Paulo: Ceres, 2011 . p.443-449.

BIANCHINI, A.; MARANGONI, A. C.; CARNEIRO, S. M. T. P. G. Doenças do feijoeiro. In: KIMATI, H.; AMORIM, L.; BERGAMIN FILHO, A.; CAMARGO, L. E. A.; REZENDE, J. A. M. Manual de fitopatologia: doenças das plantas cultivadas. São Paulo: Agronômica Ceres, 2005. p. 333-350.

BRASIL. Manual de análise sanitária de sementes. Brasília: CLAV; DNDV; SNAD; MA, 2009. 200p.

CAMPBELL, C. L.; MADDEN, L. V. Introduction to plant disease epidemiology. New York. J. Wiley \& Sons, 1990. 532p.

CÂNDIDA, D. V.; COSTA, J. G. C.; RAVA, C. A.; CARNEIRO, M. S. Controle genético da murcha de fusário (Fusarium oxysporum) em feijoeiro comum. Tropical Plant Pathology, v.34, n.6, p.379384, 2009.

CARVALHO, M. L. M.; VON PINHO, E. V. R. Armazenamento de sementes. Curso de Pós-Graduação "Lato Sensu” (Especialização) a Distância - Produção e Tecnologia de Sementes. Lavras: UFLA/ FAEPE, 1997.67p.

COMPANHIA NACIONAL DE ABASTECIMENTO - CONAB. Acompanhamento da Safra Brasileira de Grãos 2014/2015, Monitoramento Agrícola Cultivos de verão, $2^{\mathrm{a}}$ safra e de inverno Safra 2014/15. Brasília: Conab, 2015.

CRUCIOL, G. C. D.; COSTA, M. L. N. Influência de metodologias de inoculação de Macrophomina phaseolina no desempenho de cultivares de soja. Summa Phytopathologica, v.43, n.4, p.337343, 2017.

ESTRELA, L. M. B.; ALMEIDA, A. S.; RIETJENS, A. R.; COSTA, M. A. G. C.; MARTINS, R. D.; DECLOQUEMENT, J.; SOUZA, K. A.;
PAZ-LIMA, M. L. Isolamento e sintomatologia da podridão-docolo em cultivares comerciais de feijoeiro comum. In: Anais do V Congresso Estadual de Iniciação Científica, Iporá, GO, 2016.

GOMES, C. J. A. Macrophomina phaseolina em soja, padrão de ocorrência, danos e aspectos físicos, químicos e biológicos do solo relacionados à doença. Dissertation (Mestrado em Agronomia), Universidade Estadual do Norte do Paraná, Bandeirantes, 2014. 39p.

HENNING, A. A. Patologia e tratamento de sementes: noções gerais. 2 ed. Londrina: Embrapa Soja (Documentos 264), 2005. 52p.

HERNÁNDEZ-DELGADO, S.; REYES-VALDÉS, M. H.; ROSALESSERNA, R.; MAYEK-PÉREZ, N. Molecular markers associated with resistance to Macrophomina phaseolina (Tassi) Gold. in common bean. Journal of Plant Pathology, v.91, p.163-170, 2009.

INSTITUTO AGRONÔMICO - IAC. Cultivares de feijoeiro do IAC. Available from: <http://www.iac.sp.gov.br/areasdepesquisa/ graos/feijao.php>. Accessed on: Jan. 2018.

ITO, M. F.; CASTRO, J. L.; MENTEN, J. O. M.; MORAES, M. H. D. Importância do uso de sementes sadias de feijão e tratamento químico. O Agronômico, Campinas, v.55, n. 1, p.14-16, 2003.

KIMATI, H.; AMORIM, L.; REZENDE, J. A. M.; BERGAMIN FILHO, A.; CAMARGO, L. E. A. Manual de fitopatologia: doenças das plantas cultivadas. São Paulo: Ceres, 2005.

LIMA, G. S. A.; ASSUNÇÃO, I. P.; VALLE, L. A. C. Controle genético de doenças radiculares. In: MICHEREFF, S. J.; ANDRADE, D. E. G. T.; MENEZES, M. Ecologia e manejo de patógenos radiculares em solos tropicais. Recife: Imprensa Universitária, 2005. p.247-278.

MARCOS FILHO, J. Seed vigor testing: an overview of the past, presente and future perspective. Scientia Agricola, v.72, n.4, p.363-374, 2015.

MARINGONI, A. C.; LAURETTI, R. L. B. Reação de genótipos de feijoeiro comum a Fusarium oxysporum f.sp. phaseoli, Macrophomina phaseolina e Xanthomonas campestris pv. phaseoli. Revista Pesquisa Agropecuária Brasileira, v.34, n.4, p.535-542, 1999.

MAYÉK-PÉREZ, N.; LÓPES-CASTANEDA, C.; GONZÁLEZCHAVIRA, M.; GARCIA-ESPINOSA, R.; ACOSTA-GALLEGOS, J.; VEGA, O. M.; SIMPSON, J. Variability of Mexican isolates of Macrophomina phaseolina based on pathogenesis and AFLP genotype. Physiological and Molecular Plant Pathology, v.59, n.5, p.257-264, 2001.

NEERGARD, P. Seed pathology. New York: John Wiley, 1977. 839p.

PAULA JÚNIOR, T. J. de; VIEIRA, R. F.; ZAMBOLIM, L. Manejo integrado de doenças do feijoeiro. Informe Agropecuário, v.25, n.223, p.99-112, 2004. 
PAZ LIMA, M. L.; LEMES, N. M.; RIET JENS, A. R.; SILVA, J. M.; LIMA, J. B.; INÁCIO, R. V.; TEIXEIRA, S. A. C. Avaliação temporal da incidência de podridão-do-colo e murcha em cultivares comerciais de feijoeiro comum. In: Anais do 49० Congresso Brasileiro de Fitopatologia, 29 de agosto a 1 de setembro, Maceió, AL. 2016, CD-Rom.

PEREIRA, M. J. Z.; RAMALHO, M. A. P.; ABREU, A. F. B. Estratégias para eficiência da seleção de feijoeiro comum quanto á resistência à murcha-de-fusário. Pesquisa Agropecuária Brasileira, v.43, n.6, p.721-728, 2008.

PINTO, C. C. Atributos produtivos e qualitativos de grãos e fisiológicos e sanitários das sementes de cultivares de feijão. 2015.73p. Dissertation (Master's in Agronomy), Universidade Estadual Paulista, Jaboticabal, 2015.

RAVA, C. A.; SARTORATO, A.; COSTA, J. G. C. Reação de genótipos de feijoeiro comum ao Fusarium oxysporum f.sp. phaseoli em casa-de-vegetação. Fitopatologia Brasileira, v.21, p.296-300, 1996.

RAVA, C. A.; PURCHIO, A.; SARTORATO, A. Caracterização de patótipos de Colletotrichum lindemuthianum que ocorrem em algumas regiões produtoras de feijoeiro comum. Fitopatologia Brasileira, v. 19, p. 167-172, 1994.
RIBEIRO, C. A. G.; FERRAZ, S. Resistência varietal do feijoeiro (Phaseolus vulgaris L.) a Fusarium oxysporum f. sp. phaseoli. Fitopatologia Brasileira, Brasília, v.9, n.1, p.37-44, 1984.

RIBEIRO, R. L. D.; HAGEDORN, D. J. Screening for resistance to and pathogenic specialization of Fusarium oxysporum f. sp. phaseoli the causal agent of the bean yellows. Phytopathology, v.69, n.3, p.272-276, 1979.

SALA, G. M.; ITO, M. F.; CARBONELL, S. A. M. Reação de genótipos de feijoeiro comum a quatro raças de Fusarium oxysporum f. sp. phaseoli. Summa Phytopathologica, v.32, n.3, p.286-287, 2006

SALES JUNIOR, R.; MEDEIROS, E. V.; ANDRADE, D. E. G. T.; PERUCH, L. A. M.; RODRIGUES, V. J. L. B. Controle químico de doenças radiculares. In: MICHEREFF, S. J.; ANDRADE, D. E. G. T.; MENEZES, M. Ecologia e manejo de patógenos radiculares em solos tropicais. Recife: Imprensa Universitária, 2005. p.345-365.

XUE, R.; WU, J.; ZHU, Z.; WANG, L.; WANG, X.; WANG, S.; BLAIR, M.W. Differentially expressed genes in resistant and susceptible common bean (Phaseolus vulgaris L.) genotypes in response to Fusarium oxysporum f.sp. phaseoli. PLOS ONE, v.10, n.6, p.120,2015 